\title{
P-cadherin expression in feline mammary tissues
}

\author{
A Catarina Figueira ${ }^{1,2^{*}}$, Júlio Carvalheira ${ }^{3}$, M Manuela Lacerda ${ }^{4}$, M Fátima Gärtner ${ }^{3,5}$ \\ From 16th International Charles Heidelberger Symposium on Cancer Research \\ Coimbra, Portugal. 26-28 September 2010
}

Placental cadherin (P-cadherin) is a classical cadherin [1] expressed by myoepithelial cells of the human mammary gland $[2,3]$. Changes to P-cadherin expression have been observed and implicated in human breast carcinogenesis [4-6]. Feline mammary tumours show similarities with the women tumours concerning many histological characteristics and clinical evolution, being proposed as good animal model to study mammary carcinogenesis [7].

To study P-cadherin expression in feline mammary gland an immunohistochemistry assay was performed in 61 samples of normal $(n=4)$, hyperplastic $(n=12)$, benign $(n=6)$ and malignant $(n=39)$ feline mammary tissues and the immunostaining assessment was based on the estimated percentage of luminal epithelial cells labeling (aberrant expression).

In normal mammary gland, mammary hyperplasia and benign tumours, P-cadherin immunolabelling was restricted to myoepithelial cells. Nevertheless, in malignant tumours there was an aberrant epithelial Pcadherin immunoexpression in $64,1 \%(n=25)$ of the cases, with a membranar and/or cytoplasmic pattern of cellular distribution. Consequently, P-cadherin expression in feline mammary lesions was not exclusive of myoepithelial cells.

It was possible to observe a significant statistical correlation between P-cadherin expression intensity and feline mammary lesions $(p=0.0001)$. In malignant mammary tumors a statistical correlation between $\mathrm{P}$-cadherin immunoexpression intensity and histological grade was observed $(\mathrm{p}=0.0132)$. Aberrant epithelial $\mathrm{P}$-cadherin expression seems to be correlated with tumor malignancy in feline mammary gland.

* Correspondence: acfigueira@gmail.com

${ }^{1}$ Medical Faculty, University of Porto, Porto, Portugal

Full list of author information is available at the end of the article

\section{Author details}

${ }^{1}$ Medical Faculty, University of Porto, Porto, Portugal. ${ }^{2}$ Department of Veterinary Medicine, University School Vasco da Gama, Coimbra, Portugal. ${ }^{3}$ Institute of Biomedical Sciences of Abel Salazar (ICBAS), University of Porto, Porto, Portugal. ${ }^{4}$ Portuguese Institute for Oncology at Coimbra (IPO de Coimbra, EPE), Coimbra, Portugal. ${ }^{5}$ Institute of Molecular Pathology and Immunology of the University of Porto (IPATIMUP), Porto, Portugal.

\section{Published: 24 September 2010}

\section{References}

1. Nollet F, Kools P, van Roy F: Phylogenetic analysis of the cadherin superfamily allows identification of six major subfamilies besides several solitary members. J Mol Biol 2000, 299:551-572.

2. Cowin P, Rowlands TM, Hatsell SJ: Cadherins and catenins in breast cancer. Curr Opin Cell Biol 2005, 17:499-508.

3. Paredes J, Correia AL, Ribeiro AS, Albergaria A, Milanezi F, Schmitt FC P-cadherin expression in breast cancer: a review. Breast Cancer Res 2007 9:214

4. Gamallo C, Moreno-Bueno G, Sarrió D, Calero F, Hardisson D, Palacios J: The prognostic significance of $\mathrm{P}$-cadherin in infiltrating ductal breast carcinoma. Mod Pathol 2001, 14:650-654.

5. Paredes J, Milanezi F, Viegas L, Amendoeira I, Schmitt F: P-cadherin expression is associated with high-grade ductal in situ of the breast. Virchows Arch 2002, 440:16-21.

6. Paredes J, Albergaria A, Oliveira JT, Jerónimo C, Milanezi F, Schmitt FC: $\mathrm{P}$-cadherin overexpression is an indicator of clinical outcome in invasive breast carcinomas and is associated with $\mathrm{CDH} 3$ promoter hypomethylation. Clin Cancer Res 2005, 11:5869-5877.

7. Misdorp W, Weijer K: Animal Model of Human Disease. Breast Cancer. Am J Pathol 1980, 98:573-576.

doi:10.1006/jmbi.2000.3777

Cite this article as: Figueira et al:: P-cadherin expression in feline mammary tissues. BMC Proceedings 2010 4(Suppl 2):P12.

Submit your next manuscript to BioMed Central and take full advantage of:

- Convenient online submission

- Thorough peer review

- No space constraints or color figure charges

- Immediate publication on acceptance

- Inclusion in PubMled, CAS, Scopus and Google Scholar

- Research which is freely available for redistribution 